\title{
Türk Bankacılık Sektörünün Kârlılık Analizi
}

\section{Profitability Analysis of Turkish Banking Sector}

\author{
H. Aydın OKUYAN ${ }^{1}$, Yasemin KARATAŞ²
}

\begin{abstract}
ÖZET:
Bu çalışmanın amacı Türkiye'de ticari bankacılık sektöründe kârlılığı etkileyen faktörlerin neler olduğunu belirlemektir. Bu amaçla 2002 q4 2013q4 tarihleri arasındaki üçer aylık bilançolar panel veri yöntemi ile analiz edilmiştir. Çalışmanın sonucunda özkaynak yeterliliği, mevduatın büyüklüğü, personel giderlerinin fazlalığı, ana faaliyet gelirlerinin yüksekliği, aktif büyüklük, tüfe ve gayri safi yurt içi hasılanın karlılığı pozitif yönde; likit varlıkların fazlalığı, takipteki kredilerdeki artışların ise karlılığı negatif yönde etkilediği görülmüştür. Ayrıca kredilerin aktiflere oranı ve ihracatın ithalatı karşılama oranının kârlılık üzerinde anlamlı bir etkisi bulunamamıştır.
\end{abstract}

Anahtar Kelimeler: Ticari Bankalar, Banka Karlılığı, Türk Bankacılık Sektörü

\begin{abstract}
The aim of this study is to determine the factors that affect the profitability in commercial banking sector. For this purpose, quarterly balance sheets between the period 2002:q4 - 2013:q4 were analyzed by using panel data methods. In the conclusion the capital adequacy, size of deposit, in excess of personel expenses, the main operating income, size of assets, GDP, CPI variables positively affect the profitability; the excess of liquid assets and non-performing loans variables negatively affect the profitability. Also, the ratio of loans to assets and the ratio of exports to imports has been found no significant effect on profitability.
\end{abstract}

Keywords: Commercial Banks, Bank Profitability, Turkish Banking Sector

\section{GiRiş}

Bankalar, finans sektörünün temel kurumlarıdır. 2014 yıl sonu verilerine göre yaklaşık 1.300 kuruluşun faaliyet gösterdiği finans sektöründe 48 banka, sektörün aktif büyüklüğünün yaklaşık \%80'ini oluşturmaktadır. Bu kadar önemli bir payı olan bankaların güçlü ve kârlı bir yapıya sahip olmaları ekonomi açısından önemlidir. Güçlü ve kârlı bir bankacılık sistemi makroekonomik şoklara karşı ekonomiyi daha dayanıklı hale getirir ve finansal istikrarın sağlanmasında önemli bir rol oynar. King ve Levine (1993), Rajan ve Zingales (1998); DemirgüçKunt ve Maksimovic (1998); Levine (2005), Auwalin (2011), Lin ve diğerleri (2012), bankacılık sektörünün gelişmesi ile ekonomik büyüme arasında pozitif bir ilişki olduğuna işaret etmişlerdir.

Bankacılık sektörünün sağlam bir yapıya sahip olması, sektörün kârlılık düzeyi ile yakından ilişkilidir. Çünkü kâr, bütün işletmeler için en önemli oto finansman kaynağıdır ve sermaye yapısının kuv- vetlendirilmesi için gerekli koşuldur. Ayrıca kârlılık, bankaların sektördeki rekabet güçlerinin ve aktiflerin yönetim kalitesinin bir göstergesi, ayrıca risk taşıma kapasitesinin ve sermaye yapısını güçlendirebilme intimalinin belirleyicisidir.

Türkiye ekonomisinde -2002 yılından sonra yaşanan istikrarlı ve yüksek hızda büyümenin ardından- 2008 yılının başından itibaren yaşanan küresel kriz Türkiye'deki finansal sektörü de önemli ölçüde etkilemiştir. Ancak 1999 yılındaki bankacılık sektörü krizinden alınan dersler sonucu, bankaların bilançolarının sağlam olması ve risklerin dengeli dağıtılarak etkin risk yönetim politikalarının uygulanması sonucunda Türkiye'deki bankacılık sistemi 2009 yılını güven içinde geçirerek, kamu açısından bir sorun teşkil etmemiş, aksine ekonomik faaliyetlerinin finansmanını desteklemiştir. Bankacılık sektörü, 2009 yılında hem yurt içinde hem de yurt dışında anlatılan -tabiri caizse- "Türkiye'nin iyi hikâyesi" olmuştur. 2009 yılı sonu itibariyle -bir önceki yılın sonuyla 
kıyaslandığında- finansal kurumların piyasa değerleri toplamı \%113 artarak, 96 milyar \$ seviyesine çıkmıştır. Yine 2009 yılı itibariyle, bankaların özsermaye getirisi 2,8 puan artarak \%18,3 düzeyinde gerçekleşmiş, net dönem karı ise \%52 oranında artarak 19,5 milyar TL'ye yükselmiştir (Bankalarımız, 2009: i-7).

Bu çalışmanın amacı Türkiye'deki ticari bankaların kârlııı düzeylerini etkileyen unsurların belirlenmesidir. Söz konusu unsurların belirlenmesi gerek banka yöneticileri gerekse ulusal ve uluslararası yatırımcılar açısından önemlidir. Konu daha önce literatürde çokça işlenmiş, farklı veri setleri ve tarih aralıklarında incelenmiş bir konudur. Ancak ülkemizde 2002-2013 dönemlerini kapsayan bir araştırma bulunmamaktadır. Bu çalışmanın kapsadığı dönem ve verilerin frekansı itibarı ile güncel literatüre katkıda bulunabileceği düşünülmektedir. Ayrıca bu araştırmaya dair önemli sayılabilecek özelliklerden biri de, çalışmanın uygulama kısmında yer alan bankaların karlılığına ilişkin açıklayıcı değişkenlerin, daha önce incelenen çalışmaların hiç birinde bir arada aynı modelde yer almamış olmasıdır. Bu çalışmada literatürdeki diğer çalışmalardan farklı olarak mümkün olan en yüksek sayıda bağımsız değişkenin analize dahil edilmeye çalışılımıştır. Çalışmada bilanço dahilindeki faaliyetlerin banka kârlılığına olan etkisi incelenerek sistemin kârlı ve etkin bir şekilde devamı için ön plana çıkan faktörlere dikkat çekilecektir. Çalışmanın giriş bölümünden sonra ikinci bölümünde konuya ilişkin literatür incelenecek, üçüncü bölümünde veriler, yöntem ve değişkenlere yer verilecek ve dördüncübölümünde bulgular açıklanacaktır. Sonuç bölümünde ise elde edilen sonuçlar çerçevesinde konu tartışılacaktır.

\section{LITERATÜR ÖZETi}

Çalışmanın bu bölümünde banka kârlıı̆̆ının belirleyicilerini araştıran çalışmalar ve elde edilen sonuçlar incelenecektir. Bu konuda gerek yurtiçinde gerekse yurtdışında yapılmış çok sayıda çalışma mevcuttur.

Demirgüç-Kunt ve Huizinga (1999), 80 ülkeden 7900 bankanın 1988-1995 yılları arasındaki verilerini kullanarak, net faiz marjı ve vergi öncesi aktif getirisinin üzerinde etkili olan faktörleri araştırmışlardır. Özkaynakların aktiflere oranının arttıkça kârlıı̆̆ın arttığı, faiz getirisi olmayan aktiflerin arttıkça kârlılığın azaldığı, kredilerin aktiflere oranı arttıkça net faiz marjının arttığı ancak kârlılığın azaldığı, mevduatların toplam aktiflere oranı arttıkça vergi öncesi aktif getirisinin azaldığı ve genel giderler arttıkça net faiz marjının arttığı, ancak kârlılığın azaldığı sonucuna ulaşmışlardır. Çalışmada finansal gelişmenin bankacılık sistemine olan etkisine de dikkat çekilmiştir. Bir ülkede bankacilık sektörünün gelişmesine paralel olarak rekabetin arttığını bunun da kârlılığı azalttığı sonucuna ulaşmışlardır. Ayrıca yabancı bankaların gelişmiş ülkelerde yerli bankalara oranla daha küçük bir net faiz marjıla, gelişmekte olan ülkelerde ise daha büyük bir net faiz marjıyla çalıştıkları ortaya konulmuştur. Bu sonuç gelişmekte olan ülkelerdeki yabancı bankaların yerli bankalara oranla daha kârlı çalıştıkları şeklinde yorumlanmıştır.

Saunders ve Schumacher (2000), yedi gelişmiş ekonomide 1988-1995 yılları arasındaki verileri kullanarak 614 bankanın net faiz marjlarının belirleyicilerini araştırdıkları çalışmalarında Ho ve Saunders (1981) çalışmasını örnek almışlardır. Elde edilen sonuçlara göre net faiz marjı ile faiz getirisi olmayan aktiflerin toplam aktiflere oranı ve özkaynak oranı arasında pozitif bir ilişkiye rastlanmıştır. Ayrıca faiz oranı oynaklığı ile net faiz marjı arasında da yine pozitif bir ilişki olduğu ortaya konulmuştur.

Abreu ve Mendes (2002) çalışmalarında Avrupa ülkelerindeki bankaların faiz marjı ile kârlııı bileşenleri analiz etmektedir. Sonuçta sermaye tabanları güçlü bankaların beklenen iflas maliyetlerinin daha düşük olduğunu ve bunun bankanın kârlıığını artırdığını ifade etmişlerdir. Ayrıca bankanın kârlılığı ile işsizlik arasında negatif enflasyon arasında pozitif bir ilişkiye işaret etmişlerdir.

Demirgüç-Kunt, Laeven ve Levine (2004) farklı gelişmişlik düzeylerinde toplam 72 ülkede işgören 1400 'den fazla bankanın verilerini kullanarak banka düzenlemelerinin, piyasa yapısının ve ulusal kurumların net faiz marjı ve genel giderler üzerindeki etkilerini incelemişlerdir. Bağımlı değişkenler olan faiz marjları ve genel giderler üzerinde bankacılık düzenlemelerinin, sektördeki yoğunlaşma oranının ve enflasyonun pozitif etki yaptığını ancak yoğunlaşma oranının faiz marjlarına ve genel giderlere olan etkisinin rekabet üzerindeki düzenleyici engellemeler kontrol edildiğinde kaybolduğunu göstermişlerdir.

Maudos ve Guevara (2004), beş Avrupa ülkesinde 1993-2000 yılları arasındaki verileri kullanarak net faiz marjlarının belirleyicilerini incelemişlerdir. Sonuçta, banka sektördeki yoğunlaşma oranlarının marjlar üzerinde pozitif etkili olduğu ancak faiz oranı riskinin, kredi riskinin ve operasyonel mali- 
yetlerin azalması nedeniyle bu etkinin bastırıldığı ve net faiz marjlarının bu nedenle gerilediği ortaya çıkmıştır. Ayrıca, banka ücret ve komisyon gelirlerinin toplam gelirler içerisindeki payının artmasının net faiz marjlarını azalttığına vurgu yapılmıştır. Jamal, Hamidi ve Karim (2012) tarafından yapılan çalışmada Malezya'daki 16 ticari bankanın kârlılığını etkileyen makroekonomik faktörlerin incelenmesi amaçlanmıştır. Çalışmanın bağımlı değişkeni aktif kârlıı̆ı olarak belirtilmiştir. Çalışmanın bağımsız değişkenleri ise enflasyon, ekonomik büyüme, faiz oranı, sermaye piyasalarının gelişmişlik düzeyi olarak belirtilmiştir. Çalışmada panel veri analizi yöntemi kullanılmıştır. Çalışmanın sonuçlarında aktif kârlılı̆ıını enflasyon, ekonomik büyüme, faiz oranının pozitif yönde; sermaye piyasalarının gelişmişlik düzeyinin ise negatif yönde etkilediği ifade edilmiştir.

Riaz (2013) tarafından yapılan çalışmada Pakistan'da 2006-2010 döneminde 32 ticari bankanın kârııı̆ını etkileyen bankalara özgü ve makroekonomik değişkenlerin incelenmesi amaçlanmıştır. Çalışmanın bağımlı değişkenleri aktif kârlıı̆ı ve özkaynak kârlıı̆ı olarak belirtilmiştir. Çalışmanın bağımsız değişkenleri ise büyüklük, kredi riski, mevduat/aktifler, faiz oranı, faaliyet verimliliği, toplam kredi/toplam aktif, gayrisafi yurtiçi hasıla oranı, tüketici fiyat endeksi olarak ifade edilmiştir. Çalışmada regresyon analizi yöntemi kullanılmıştır. Çalışmanın sonuçlarında aktif kârlılığını kredi riski, faaliyet verimliliği, gayrisafi yurtiçi hasıla oranının pozitif yönde; tüketici fiyat endeksi ve faiz oranının negatif yönde etkilediği ifade edilmiştir. Özkaynak kârlııı̆ını ise toplam kredi/toplam aktif, mevduat/ aktifler, gayrisafi yurtiçi hasıla oranı, büyüklük değişkenlerinin pozitif yönde; kredi riski, faaliyet verimliliği, faiz oranı ve tüketici fiyat endeksinin negatif yönde etkilediği ifade edilmiştir.

Onuonga (2014) tarafından yapılan çalışmada Kenya'da 2008- 2013 döneminde altı büyük ticari bankanın kârlıı̆ııı belirleyen içsel faktörlerin incelenmesi amaçlanmıştır. Çalışmanın bağımlı değişkeni aktif kârlılığı olarak belirtilmiştir. Çalışmanın bağımsız değişkenleri ise faiz dışı gelirler/toplam faaliyet gelirleri, toplam faaliyet giderleri/toplam aktifler, toplam krediler/toplam aktifler, mülkiyet (sahiplik), aktif logaritması, özkaynaklar/aktifler olarak ifade edilmiştir.

Çalışmada genelleştirilmiş en küçük kareler yöntemi kullanılımış ve değerlendirmeler bu yönteme göre yapılmıştır. Çalışmanın sonuçlarında ise aktif kârııı̆ını faiz dışı gelirler/toplam faaliyet gelirleri, toplam krediler/toplam aktifler, mülkiyet (sahiplik), aktif logaritması, özkaynaklar/aktifler değişkenlerinin pozitif yönde; toplam faaliyet giderleri/toplam aktifler değişkenin ise negatif yönde etkilediği ifade edilmiştir.

Pan ve Pan (2014) tarafından yapılan çalışmada Çin'de 1998-2012 döneminde yer alan 10 ticari bankanın kârlılığını belirleyen dışsal faktörlerin incelenmesi amaçlanmıştır. Çalışmanın bağımlı değişkeni aktif kârlılığı olarak belirtilmiştir. Çalışmanın bağımsız değişkenleri ise ekonomik büyüme, para poltikası, enflasyon, finansal pazardaki gelişmeler olarak belirtilmiştir. Çalışmada panel veri analizi yöntemi kullanılmıştır. çalışmanın sonuçlarında aktif kârlıığını ekonomik büyüme, enflasyon ve para politikalarının pozitif yönde; finansal pazardaki gelişmelerin ise negatif yönde etkilediği ifade edilmiştir. Kiganda (2014) tarafından yapılan çalışmada Kenya'da 20082012 döneminde banka kârlıığı üzerinde etkili olan makroekonomik değişkenlerin incelenmesi amaçlanmıştır. Çalışmanın bağımlı değişkeni aktif kârlıı̆̆ı olarak belirtilmiştir. Çalışmanın bağımsız değişkenleri gayrisafi yurtiçi hasıla, enflasyon, döviz kuru olarak belirtilmiştir. Çalışmada sıradan en küçük kareler yöntemi kullanılmıştır. Çalışmanın sonuçlarında gayrisafi yurtiçi hasıla, enflasyon ve döviz kurunun 2008-2012 döneminde yer alan özkaynakla sınırlanmış bankaların kârlılıkları üzerinde önemli bir etkisinin olmadığı ifade edilmiştir.

Kaya (2002), çalışmasında Türk bankacılık sisteminde 1997-2000 yılları arasında net faiz marjının, aktif getirisinin ve özkaynak getirisinin mikro ve makro belirleyicilerini araştırmıştır. Elde edilen sonuçlara göre, net faiz marjı ile özkaynaklar, likit varlıklar, personel harcamaları ve bankaların pazar payı arasında pozitif, mevduatların toplam aktiflere oranı arasında negatif ilişki bulunmaktadır. Aktif kârlılığı ile özkaynaklar, likit varlıklar ve kredilerin toplam aktiflere oranı arasında pozitif; personel harcamaları, mevduatlar ve net tahsili gecikmiş alacakların toplam aktiflere oranı arasında negatif ilişki vardır. Özkaynak kârlıı̆ının ise özkaynaklar, personel harcamaları ve mevduatlar ile negatif; menkul değerler cüzdanı, likidite, krediler, yabancı para pozisyonu ve piyasa payı ile pozitif ilişki içinde olduğu sonucuna varılmıştır. Tunay ve Silpar'ın (2006), çalışmalarında Türk bankacılık sektörünün kârlıık performansını etkileyen mikro ve makro değişkenleri araştırmışlardır. Çalışmanın sonucunda ticari bankaların kârlılıklarını 
etkileyen unsurların kredilerin toplam aktiflere oranı, toplam aktiflerin logaritması, faiz dışı gelirlerin toplam aktiflere oranı, enflasyon oranı, reel milli gelir, mevduatların hisse senedi piyasası kapitalizasyon değerine oranı, hisse senedi kapitalizasyon değerinin milli gelire oranı ve toplam aktiflerin milli gelire oranı olduğu ortaya konulmuştur. Atasoy (2007) çalışmasında 1990 - 2005 yılları arasında Türk bankacılık sektöründe gelir gider yapısı ve kârlıığın belirleyicilerini ortaya koymaya çalışmıştır. Elde edilen sonuçlar aktif kârlılığı üzerinde özkaynak getirisi, varlık büyüklüğü ve enflasyon oranının pozitif; sektörde yoğunlaşma, bankacılık sektörü büyüklüğü ve duran varlık oranının negatif etki ettiğini ortaya koymuştur. Sayılgan ve Yıldırım (2009) Türk bankacılık sektöründe 2002 - 2007 yılları arasındaki döneme ait aylık verileri kullanarak varlık kârlıığı ve öz kaynak kârlıı̆̆ının belirleyicilerini araştırmışlardır. Kârıılık üzerinde sanayi üretim endeksindeki artışların ve özkaynak kullanım oranının pozitif, enflasyonun ve bilanço dışı varlık kullanımının negatif bir etki yaptığını öne sürmüşlerdir. Alp ve diğerleri (2009) 2002-2009 yıllarını kapsayan dönemde Türkiye'de faaliyet gösteren bankalarda, varlık getirisi olarak tanımladıkları kârlılığın içsel belirleyicilerini tespit etmeye çalışmışlardır. Çalışmanın sonuçları bankaların sermaye yeterliliğinin ve büyüklüğünün artmasının kârlılığı olumlu yönde; likiditesinin ve faaliyet giderlerinin artmasının ise kârlılığı olumsuz yönde etkilediğini göstermektedir. Dağıdır (2010) sanayi üretim endeksi, üretici fiyat endeksi ve gayrısafi yurtiçi hasıla değişkenlerinin banka kârlıığını nasıl etkilediğini araştırmıştır. Sonuçta faiz marjı ile sanayi üretim endeksi, gayrısafi yurtiçi hasıla ve üretici fiyat endeksi değişkenlerinin eşbütünleşik oldukları ve uzun dönemde paralel hareket ettikleri sonucuna ulaşıımıştır. Ayrıca büyümenin banka kârlıığı üzerinde etkili olmadığı, enflasyon ve büyümenin ise banka kârlılığını negatif yönde etkilediği öne sürülmüştür. Taşkın (2011) çalışmasında Türkiye'de 1995-2009 yılları arasında faaliyet gösteren ticari bankaların performanslarını etkileyen içsel ve dışsal faktörleri belirlemeye çalışmıştır. Kârlılık ölçütü olarak aktif kârlıı̆̆ı, net faiz marjı ve özkaynak kârlıı̆̆ının kullanıldığı çalışmada elde edilen sonuçlar bankacılık performansının daha çok mikro değişkenlerden etkilendiğini ve makroekonomik faktörlerin anlamlı düzeyde bir etkisinin olmadığı ortaya konulmuştur. Ancak ekonominin genel olarak istikrarlı durumda olmasının banka kârlılığını etkilediği ifade edilmiştir. Doğru (2011) çalışmasında bankaların kârlılık göstergeleri olan net faiz marjı, aktif getirisi ve özkaynak getirisi üzerinde etkili olan, bankacılığa özgü değişkenleri ortaya koymaya çalışmıştır. Belirtilen üç farklı kârlılık göstergesinde de, personel harcamaları ile bağımlı değişkenler arasında pozitif yönlü bir ilişkinin varlığı ortaya konulmaktadır. Bankanın personel harcamaları ve faiz dışı giderler üzerindeki etkinliğinin kârlılık üzerinde doğrudan ve yüksek bir etki yarattığı görülmüştür. Çalışmada bankanın aktifindeki büyüme, kârlılığını olumlu yönde etkilerken, kredilerindeki büyüme kârlılığı ve yüksek faiz marjını desteklememektedir.

Alper ve Anbar (2011) çalışmalarında 2002 - 2010 yılları arasında Türkiye'deki bankaların kârlılıkları üzerinde etkili olan bankaya ait ve makroekonomik değişkenleri ortaya koymayı amaçlamışlardır. Bağımlı değişken olarak aktif ve özkaynak getirisinin kullanıldığı çalışmada, aktif büyüklüğün ve faiz dışı gelirlerin banka kârlılı̆̆ı üzerinde pozitif yönde önemli bir etkiye sahip olduğu ortaya konulmuştur. Takipteki kredilerin boyutu ve kredi portföyü büyüklüğünün ise kârlııı üzerinde negatif ve güçlü bir etkisi olduğu ifade edilmiştir. Makroekonomik değişkenlerden sadece reel faizin kârlıı̆ı olumlu yönde etkilediği öne sürülmüş, çalışma çerçevesinde ele alınan diğer makroekonomik faktörlerin kârlılık üzerinde etkili olmadığı ortaya konulmuştur. Bu sonuçlara göre, bankaların kredilerin aktiflere oranını azaltmak, büyüklüğü ve faiz dışı gelirleri artırmak yoluyla kârlııklarını artırabileceği söylenmiş, reel faizin yükseldiği dönemlerde kârlıı̆ın artacağı sonucuna varılmıştır. Kırkulak Uludağ ve Gökmen (2011) çalışmalarında 1999-2009 yılları arasında Türk bankacılık sektöründe kârlılığın belirleyicilerini tespit etmeye çalışmışlardır. Bulgular aktif büyüklüğü fazla olmayan bankaların aktiflerini iyi kullanarak yüksek kârlar elde ettiklerini, özsermayesi düşük olan bankaların daha kârlı olduklarını ve yabancı bankaların personel verimliliklerinin yüksek olduğunu ortaya koymuştur. Enflasyon oranı ile kârlıık arasında pozitif ilişki saptanırken, ekonomik büyümeye paralel olarak bankaların kârlarının arttığı tespit edilmiştir. Çalışmada ayrıca banka kârlarının oynak bir yapıya sahip olduğunu ve Türk bankacılık sektöründe elde edilen kârların istikrarlı olmadığı sonucuna da varılmıştır.

Tablo 1'de literatür bölümünde özetlenen çalışmaları da kapsayacak şekilde hazırlanmış olan ve çalışmalarda kullanılan bağımlı ve bağımsız değişkenleri gösteren bir tablo sunulmuştur. 
Tablo 1: Banka Karlıı̆̆ı üzerine Yapılan Çalışmalarda Kullanılan Değişkenler

\begin{tabular}{|c|c|c|}
\hline $\begin{array}{l}\text { Bağımlı } \\
\text { Değişsken }\end{array}$ & Bağımsız Değişkenler & Yazarlar \\
\hline ROA, ROE & reel faiz, yoğunlaşma oranı, kamu mülkiyeti özkaynak, personel gideri, likidite & $\begin{array}{l}\text { Molyneux ve Thornton } \\
\text { (1992) }\end{array}$ \\
\hline NIM, ROA & $\begin{array}{l}\text { duran aktif, kredi, mevduat, faiz dışı gider, yabancı mülkiyeti, reel faiz, } \\
\text { enflasyon, büyüme oranı, zorunlu karşılık oranı, vergi oranı, mevduat sigorta } \\
\text { sisteminin varlığı, yoğunlaşma, borsa piyasa kapitalizasyon }\end{array}$ & $\begin{array}{l}\text { Demirgüç-Kunt ve } \\
\text { Huizinga (1999) }\end{array}$ \\
\hline NIM & net faiz dışı gider, faiz getirisi olmayan aktifler, özkaynaklar, faiz oranı oynaklığı & $\begin{array}{l}\text { Saunders ve } \\
\text { Schumacher (2000) }\end{array}$ \\
\hline ROA, ROE, NIM & özkaynak, işsizlik oranı, enflasyon, personel gideri, kredi piyasa payı & Abreu ve Mendes (2002) \\
\hline $\begin{array}{l}\text { ROA, ROE, } \\
\text { NIM }\end{array}$ & $\begin{array}{l}\text { özkaynak, likidite, personel gideri, piyasa payı, mevduat, net takipteki alacak, } \\
\text { menkul kıymet, yabancı para pozisyonu }\end{array}$ & Kaya (2002) \\
\hline $\begin{array}{l}\text { NIM, GENEL } \\
\text { GID }\end{array}$ & $\begin{array}{l}\text { banka düzenlemeleri, piyasa yapısı, ulusal kurumlar, sektördeki yoğunlaşma } \\
\text { oranı, ekonomik özgürlük, mülkiyet hakları }\end{array}$ & $\begin{array}{l}\text { Demirgüç-Kunt, Laeven } \\
\text { ve Levine (2003) }\end{array}$ \\
\hline NIM & banka sektördeki yoğunlaşma, banka ücret ve komiyon gelirleri & Maudos ve Guevara (2004) \\
\hline ROA, NIM & $\begin{array}{l}\text { faiz gelirleri, özkaynaklar, krediler, takipteki alacaklar, faiz dışı gelirler, } \\
\text { büyüklük, enflasyon, gsmh, reel büyüme oranı }\end{array}$ & Atasoy (2007) \\
\hline NIM & faiz marjı, sanayi üretim endeksi, gsyih, enflasyon & Dağıdır (2010) \\
\hline ROA & büyüklük, risk, likidite, faaliyet giderleri, özkaynaklar & $\begin{array}{l}\text { Alp, Ban, Demirgüneş ve } \\
\text { Kılıç (2009) }\end{array}$ \\
\hline ROA, ROE & sanayi üretim endeksi, enflasyon, bilanço dışı varlık, özkaynak & $\begin{array}{l}\text { Sayılgan ve Yıldırım } \\
\text { (2009) }\end{array}$ \\
\hline ROA, ROE & $\begin{array}{l}\text { büyüklük, özkaynaklar, likidite, krediler ve takipteki krediler, mevduat, } \\
\text { gelir-gider yapısı, reel gsyih artış oranı, enflasyon, reel faiz }\end{array}$ & Alper ve Anbar (2011) \\
\hline $\begin{array}{l}\text { ROA, ROE, } \\
\text { NIM }\end{array}$ & $\begin{array}{l}\text { enflasyon, faiz oranı, } 2001 \text { krizi, büyüklük, kredi, mevduat, faiz dışı gider, } \\
\text { yabancı mülkiyeti, personel giderleri, kişi başına gsmh, sanayi üretim endeksi }\end{array}$ & Taşkın (2011) \\
\hline $\begin{array}{l}\text { ROA, ROE, } \\
\text { NIM }\end{array}$ & $\begin{array}{l}\text { kredi, özkaynak, faiz dışı gider, likit varlıklar, menkul değerler, tahsili } \\
\text { gecikmiş alacaklar, personel harcamaları, net faiz geliri }\end{array}$ & Doğru (2011) \\
\hline $\mathrm{ROA}$ & $\begin{array}{l}\text { özkaynaklar,kredi riski, personel verimliliği, büyüklük, faiz dışı } \\
\text { giderler, sahiplik yapısı, yoğunlaşma, enflasyon, büyüme }\end{array}$ & $\begin{array}{l}\text { Kırkulak-Uludağ ve } \\
\text { Gökmen (2011) }\end{array}$ \\
\hline $\mathrm{ROA}$ & $\begin{array}{l}\text { sermaye, faaliyet giderleri, likidite, menkul değerler cüzdanı, takipteki } \\
\text { krediler, büyüklük, enflasyon, gsyih büyüme oranı, sektör payı yoğunlaşma }\end{array}$ & $\begin{array}{l}\text { Gülhan ve Uzunlar } \\
\text { (2011) }\end{array}$ \\
\hline ROA, NIM & $\begin{array}{l}\text { takipteki alacaklar karşılığı/takipteki krediler, faiz dışı gider/net kar, } \\
\text { krediler/mevduatlar, faiz dışı gelir/toplam aktif, para arzındaki büyüme oranı }\end{array}$ & $\begin{array}{l}\text { Çerçi, Kandır ve Önal } \\
(2012)\end{array}$ \\
\hline ROA, ROE & sermaye yapısı, büyüklük, büyüme, kurumlar vergisi oranı & $\begin{array}{l}\text { İskenderoğlu, Karadeniz } \\
\text { ve Atioğlu (2012) }\end{array}$ \\
\hline ROA & $\begin{array}{l}\text { enflasyon, ekonomik büyüme, faiz oranı, sermaye piyasalarının gelişmişlik } \\
\text { düzeyi }\end{array}$ & $\begin{array}{l}\text { Jamal, Hamidi ve Karim } \\
(2012)\end{array}$ \\
\hline $\begin{array}{l}\text { ROA, ROE, } \\
\text { NIM }\end{array}$ & $\begin{array}{l}\text { (özel karşılıklar sonrası net faiz gelirleri, diğer faaliyet giderleri, Türk Parası } \\
\text { (TP) aktifleri)/ toplam aktifler, TP pasifleri/toplam pasifler, Yabancı Para (YP) } \\
\text { aktifleri /YP Pasifleri }\end{array}$ & $\begin{array}{l}\text { Demirel, Atakişi ve } \\
\text { Abacıoğlu (2013) }\end{array}$ \\
\hline ROA & $\begin{array}{l}\text { maliyet etkinliği, likidite, kredi portföyünün yapısı, kredi riski, sermaye } \\
\text { yeterliliği, banka büyüklüğü }\end{array}$ & Almumanı (2013) \\
\hline ROA, ROE & $\begin{array}{l}\text { büyüklük, kredi riski, mevduat/aktifler, faiz oranı, faaliyet verimliliği, } \\
\text { kredi/aktifler, gsyih, tüfe }\end{array}$ & $\operatorname{Riaz}(2013)$ \\
\hline ROA & $\begin{array}{l}\text { faiz dışı gelir/faaliyet gelirleri, } \\
\text { faaliyet giderleri/aktifler, krediler/aktifler, özkaynaklar/aktifler, aktif } \\
\text { logaritması, mülkiyet }\end{array}$ & Onuonga (2014) \\
\hline ROA & gsyih, enflasyon, döviz kuru & Kiganda (2014) \\
\hline ROA & ekonomik büyüme, para politikası, enflasyon, finansal pazardaki gelişmeler & Pan ve Pan (2014) \\
\hline
\end{tabular}

* NIM: Net Faiz Marjı, ROA:Aktif Kârlıı̆̆ı, ROE: Özkaynak Kârlılığı 


\section{ANALIZ}

\subsection{Veri Seti ve Değişkenler}

Çalışmanın veri setini Aralık 2002-Aralık 2013 döneminde Türk bankacılık sektöründe faaliyet gösteren 19 ticari bankanın finansal tablolarında yer alan veriler oluşturmaktadır. 2002 yılı öncesinde sağlıklı veriye ulaşımın sınırlı olması nedeniyle çalış- ma bu tarihten başlatılmıştır. 19 mevduat bankasına ait 45 dönemlik 769 gözlemlik panel yöntemlerle incelenecektir. Bu verilerin sağlanmasında TBB'nin resmi sitesindeki üçer aylık bilanço ve gelir tablosu verileri ile TÜiK ve TCMB adresindeki verilerden yararlanılmıştır. Çalışmada yer alan ticati bankalar aşağıda tablo halinde belirtilmiştir.

Tablo 2: Çalışmada Yer Alan Bankalar

\begin{tabular}{|c|l|c|l|}
\hline Sıra No & \multicolumn{1}{|c|}{ Bankalar } & Sıra No & \multicolumn{1}{|c|}{ Bankalar } \\
\hline 1 & T.C. Ziraat Bankası A.Ş. & 11 & Türk Ekonomi Bankası A.Ş. \\
\hline 2 & Türkiye Halk Bankası A.Ş. & 12 & Yapı ve Kredi Bankası A.Ş. \\
\hline 3 & Türkiye Vakıflar Bankası T.A.O. & 13 & Alternatifbank A.Ş. \\
\hline 4 & Akbank T.A.Ş & 14 & Arap Türk Bankası A.Ş. \\
\hline 5 & Anadolubank A.Ş. & 15 & Burgan Bank A.Ş. \\
\hline 6 & Şekerbank T.A.Ş. & 16 & Denizbank A.Ş. \\
\hline 7 & Tekstil Bankası A.Ş & 17 & Finans Bank A.Ş. \\
\hline 8 & Turkish Bank A.Ş. & 18 & HSBC Bank A.Ş. \\
\hline 9 & Türkiye Garanti Bankası A.Ş. & 19 & ING Bank A.Ş. \\
\hline 10 & Türkiye İş Bankası A.Ş. & & \\
\hline
\end{tabular}

Çalışmada kullanılan modeller aşağıda gösterilmiştir.

$\mathrm{ROA}_{\text {it }}=a+\beta_{1}[\mathrm{Kred} / \mathrm{Aktf}]_{i t}+\beta_{2}[\text { Ozkynk/Aktf }]_{\text {it }}+\beta_{3}[\text { Mevdt/Aktf }]_{i t}+\beta 4[\text { Per Gid/Aktf }]_{\text {it }}+\beta 5[$ Net Fz Gel/ Top Gel] it $+\beta 6\left[\right.$ Fz Dış Gel/Aktf] it $+\beta 7[\text { Lik Var/Aktf }]_{i t}+\beta 8[\text { Takp Kred/Top Kred] }]_{i t}+\beta$ g $\left[\right.$ Aktf Log] it $+\beta_{10}$ Tufeit $_{\text {it }}$ $+\beta_{11}$ Gsyihit $_{+} \beta_{12}$ ihr İth Karş Oran $+\varepsilon$ it

$\mathrm{i}=1 \ldots \ldots, \mathrm{N} \mathrm{t}=1 \ldots \ldots, \mathrm{T}$

ROE $i t=a+\beta_{1}[\mathrm{Kred} / \mathrm{Aktf}]$ it $+\beta_{2}[$ Ozkynk/Aktf $]$ it $+\beta 3[$ Mevdt $/$ Aktf $]$ it $+\beta 4[$ Per Gid/Aktf $]$ it $+\beta 5[$ Net Fz Gel/Top Gel] $]$ it $+\beta 6[$ Fz Dış Gel/Aktf]it $+\beta 7[$ Lik Var/Aktf $]$ it $+\beta 8[$ Takp Kred/Top Kred]it $+\beta 9[$ Aktf Log]it $+\beta 10$ Tufeit + $\beta 11$ Gsyihit $+\beta 12$ ìhr İth Karş Oran $+\varepsilon$ it

$\mathrm{i}=1 \ldots \ldots, \mathrm{N} \mathrm{t}=1 \ldots \ldots, \mathrm{T}$

NIMit $=a+\beta_{1}[\mathrm{Kred} /$ Aktf $]$ it $+\beta_{2}[$ Ozkynk/Aktf $]$ it $+\beta 3[$ Mevdt/Aktf $]$ it $+\beta 4[$ Per Gid/Aktf $]$ it $+\beta 5[$ Net Fz Gel/Top Gel] it $+\beta 6[$ Fz Dış Gel/Aktf]it $+\beta 7[$ Lik Var/Aktf]it $+\beta 8[$ Takp Kred/Top Kred]it $+\beta 9[$ Aktf Log]it $+\beta 10$ Tufeit + $\beta 11$ Gsyihit $+\beta 12$ İhr İth Karş Oran $+\varepsilon$ it

$\mathrm{i}=1 \ldots \ldots, \mathrm{N} \mathrm{t}=1 \ldots \ldots, \mathrm{T}$

Tablo 3: Bağımlı Değişkenler

\begin{tabular}{|l|l|}
\hline Aktif Kârlılığı (ROA) & Net Dönem Kârı/Toplam Aktifler \\
\hline Özkaynak Kârlıı̆ı̆ (ROE) & Net Dönem Kârı/Toplam Özkaynaklar \\
\hline Net Faiz Marjı (NIM) & Net Faiz Geliri/Toplam Aktifler \\
\hline
\end{tabular}


Modeldeki bağımsız değişkenlerden ilki krediler/ aktiflerdir (Kr/Ak). Genel ifadeyle mevduatlar krediye dönüştürüldüğü sürece net faiz marjı ve kârlılık daha da yükselecektir. Ne var ki bir banka toplam kredi toplam aktif oranını arttıııken daha çok risk alıyorsa, bu bankanın kârlarının düşmesi beklenir (Taşkın, 2011).

Özkaynaklar/Aktifler (Oz/Ak): Bu oran sermaye yeterliliği ölçütüdür. Sermaye yeterliliği ise bankanın karşılaşabileceği olası olumsuz durumların üstesinden gelmesi için yeterli olan özkaynak miktarını temsil eder.

Mevduat/Aktifler (Mv/Ak): Bankanın mevduat sahiplerinden aldığı borcunun ne kadarını aktifleriyle karşılayabildiğini temsil eder.

Personel Giderleri/Aktifler (PrG/Ak): Personel için yapılan giderlerin kârlılığı ne düzeyde etkilediğini temsil etmektedir.

Net Faiz Gelirleri/Toplam Gelir (NFG/TG): Elde edilen gelirlerin ne kadarının faizlerden elde edildiği ya da faiz artışının gelirleri ne düzeyde etkilediğini temsil etmektedir.

Faiz Dıșı Gelirler/Aktifler (FDG/Ak): Bu oran bankaIarın faaliyet çeşitliliğini temsil etmektedir.

Takipteki Krediler/ Krediler (TkpKr/TopKr): Verilen kredilerin ne kadarının takibe düştüğünü ve takibe düşen kredilerin verilen toplam krediler içindeki payının kârııı̆ı ne düzeyde etkilediğini temsil etmektedir.

Likit Varlıklar/Aktifler (LikVr/Ak): Bankaların yükümlülüklerini ve borçlarının istenildiğinde ödeyip ödeyememesini temsil eder.

Aktif Logaritması(Ak Log): Ölçek ekonomisini değerlendirmeyi temsil eder.

Tüketici Fiyatları Endeksi (Tüfe): Enflasyonun faiz oranlarının artmasına neden olarak banka kârlııı̆ına pozitif etki edebilmektedir. Bu durumu temsilen enflasyon verisi olarak tüketici fiyat endeksi kullanılmıştır.

Gayri Safi Yurtiçi Hasıla (Gsyih): Gayri safi yurtiçi hasıla oranlarının kredilerin arz ve talebine etki ettiği düşünülmektedir ve bu durumu temsilen kullanılmıştır.

İhracatın İthalatı Karșılama Oranı (IhrithKO): Kredilerin arz ve talebine etki ettiği düşünülerek değişkenler arasına dahil edilmiştir.

Çalışmanın veri setini oluşturan gözlemlere ait tanımlayıc istatistiklere Tablo 4 'te yer verilmiştir. Açıklayıcı değişkenler arasında çoklu bağlantı sorunu olup olmadığı "varyans büyütme faktörü" (vif) hesaplaması ile ortaya konulmuştur.

Tablo 4: Değişkenlere Ait Tanımlayıc İstatistik Tablosu

\begin{tabular}{|l|c|c|c|c|c|}
\hline Değişkenler & Gözlem Sayısı & Ortalama & Standart Sapma & Minimum & Maximum \\
\hline Roa & 769 & 0.0107 & 0.0090 & $(0.1021)$ & 0.0544 \\
\hline Roe & 769 & 0.0951 & 0.0957 & $(1.4213)$ & 0.6285 \\
\hline Nim & 769 & 0.0301 & 0.0181 & $(0.0369)$ & 0.1371 \\
\hline Kr /Ak & 769 & 0.5005 & 0.1654 & 0.0373 & 0.7964 \\
\hline Oz /Ak & 769 & 0.1221 & 0.0441 & 0.0098 & 0.4100 \\
\hline Mv/Ak & 769 & 0.6022 & 0.1234 & 0.0992 & 0.8591 \\
\hline PrG /Ak & 769 & 0.0223 & 0.0245 & $(0.1312)$ & 0.1747 \\
\hline 8NFG / TG & 769 & 0.6448 & 0.1860 & $(0.3424)$ & 1.5023 \\
\hline FDG / Ak & 769 & 0.0185 & 0.0188 & $(0.0193)$ & 0.1490 \\
\hline TkpKr / TopKr & 769 & 0.0615 & 0.0349 & 0.0015 & 0.1829 \\
\hline LikVr/ Ak & 769 & 0.0542 & 0.0653 & 0.0030 & 0.5163 \\
\hline Ak Log & 769 & 7.1304 & 0.7632 & 2.6373 & 8.3831 \\
\hline Tüfe & 769 & 0.0221 & 0.0161 & $(0.0032)$ & 0.0804 \\
\hline Gsyih & 769 & 0.0340 & 0.0871 & $(0.1113)$ & 0.2157 \\
\hline İhr İth KO & 769 & 3.4273 & 0.4565 & 2.6275 & 5.3376 \\
\hline
\end{tabular}




\subsection{Model Seçimi Ve Tahmin Sonuçları}

Panel veri yöntemi kullanılarak yapılan uygulamalı çalışmalarda genel olarak sabit etki (fixed effects) ve rassal etki (random effects) modeli olmak üzere iki model kullanılmaktadır. Analizde boş hipotez altında etkin tahminci ortak regresyon iken, alternatif hipotez altındaki etkin tahminci sabit etki modelidir. Çalışmada konuyla ilgili bulguların sunulduğu Tablo 8 'nin 1 . , 3. ve 5 . kolonunda sırasıyla yer alan " 8.01 ", "6.02" ve "3.43" F-testi sonuçlarına göre elde edilen test istatistiği değerleri yüzde 1 anlamlılık düzeyinde istatistiki olarak anlamlı bulunmuştur. Bu durumda boş hipotez reddedilmiştir ve ilgili iki model arasında sabit etki modeli tercih edilmiştir.

Panel veri ile yapılan çalışmalarda rassal etki modeli de kullanılabilir. Rassal etki modelinde tesadüfi etkinin sıfır olup olmadığı Breusch-Pagan testi ile test edilmektedir. Boş hipotezin reddedilmesi tesadüfi etki modelinin ortak regresyon modeline karşı tercih edilmesi gerektiğini ifade eder. Çalışmada konuyla ilgili bulguların sunulduğu Tablo 5 'in 2. , 4. ve 6.kolonunda sırasıyla yer alan "196.28",
"100.09" ve "30.15" Breusch-Pagan test sonuçlarına göre test istatistiği değerleri yüzde 1 anlamlılık düzeyinde istatistiki olarak anlamlı bulunmuştur. Bu durumda, "sıfır" rassal etki boş hipotezi reddedilir.

Tablo 5'de sunulan çalışma bulguları her ne kadar aşırı derecede değişkenlik göstermese de sabit etki ve rassal etki modelleri arasında seçim yapabilmek amacıyla modeller yuvalanmış (non-nested) formatta ya da modellerden biri diğerinin sınırlı hali olmadığı için "Hausman" spesifikasyon testi kullanılmaktadır. Bu testte, boş hipotez sabit etki modeli ile rassal etki modelinin parametreleri arasındaki farklılığın sistematik olmadığı şeklinde ifade edilmektedir.

Boş hipotezin reddedilmesi ise sabit etki modelinin rassal etki modeline tercih edilmesi gerektiğini belirtmektedir (Berke, 2009). Çalışma bulgularının yer aldığı Tablo 5'de 2. , 4. ve 6. kolonunda sırasıyla yer alan "118.89", "88.96" ve "17.75" Hausman test sonuçlarına göre rassal etki modeli reddedilip sabit etki modeli tercih edilmiştir.

Tablo 5: Ticari Bankalarda Kârlııı̆ı Belirleyen Faktörler

\begin{tabular}{|c|c|c|c|c|c|c|}
\hline & \multicolumn{2}{|c|}{$\begin{array}{l}\text { Bağımlı Değişken: Aktif } \\
\text { Kârlılığı (ROA) }\end{array}$} & \multicolumn{2}{|c|}{$\begin{array}{l}\text { Bağımlı Değişken: Özkaynak } \\
\text { Kârlılığı (ROE) }\end{array}$} & \multicolumn{2}{|c|}{$\begin{array}{l}\text { Bağımlı Değişken:Net Faiz } \\
\text { Marjı (NIM) }\end{array}$} \\
\hline & $\begin{array}{c}\text { Sabit Etki } \\
\text { Modeli }\end{array}$ & $\begin{array}{c}\text { Rassal Etki } \\
\text { Modeli }\end{array}$ & $\begin{array}{c}\text { Sabit Etki } \\
\text { Modeli }\end{array}$ & $\begin{array}{c}\text { Rassal Etki } \\
\text { Modeli }\end{array}$ & $\begin{array}{c}\text { Sabit Etki } \\
\text { Modeli }\end{array}$ & $\begin{array}{l}\text { Rassal Etki } \\
\text { Modeli }\end{array}$ \\
\hline $\mathrm{Kr} / \mathrm{Ak}$ & \begin{tabular}{|l|}
0.0010 \\
{$[0.0027]$}
\end{tabular} & \begin{tabular}{|l|}
$(0.0015)$ \\
{$[0.0025]$}
\end{tabular} & \begin{tabular}{|l|}
$(0.0193)$ \\
{$[0.0305]$} \\
\end{tabular} & \begin{tabular}{|l}
$(0.0540)$ \\
{$[0.0258]$} \\
\end{tabular} & \begin{tabular}{|l|}
0.0035 \\
{$[0.0047]$} \\
\end{tabular} & \begin{tabular}{|l|}
0.0041 \\
{$[0.0040]$} \\
\end{tabular} \\
\hline Oz /Ak & \begin{tabular}{|l|}
$0.0500^{* * *}$ \\
{$[0.0091]$} \\
\end{tabular} & \begin{tabular}{|l|}
0.0494 \\
{$[0.0086]$} \\
\end{tabular} & \begin{tabular}{|l|}
$(0.1458)$ \\
{$[0.1007]$} \\
\end{tabular} & \begin{tabular}{|l|}
$(0.2077)$ \\
{$[0.0915]$} \\
\end{tabular} & \begin{tabular}{|l|}
$0.0833^{* * *}$ \\
{$[0.0155]$} \\
\end{tabular} & \begin{tabular}{|l|}
0.0805 \\
{$[0.0141]$} \\
\end{tabular} \\
\hline Mv/Ak & \begin{tabular}{|l}
$0.0143^{* * *}$ \\
{$[0.0035]$} \\
\end{tabular} & \begin{tabular}{|l|}
0.0110 \\
{$[0.0032]$} \\
\end{tabular} & \begin{tabular}{|l|}
$0.1418^{* * *}$ \\
{$[0.0393]$} \\
\end{tabular} & \begin{tabular}{|l|}
0.0956 \\
{$[0.0333]$} \\
\end{tabular} & \begin{tabular}{|l|}
$0.0173^{* * *}$ \\
{$[0.0060]$} \\
\end{tabular} & \begin{tabular}{|l|}
0.0172 \\
{$[0.0052]$} \\
\end{tabular} \\
\hline PrG /Ak & $\begin{array}{l}0.1469 * * * \\
{[0.0158]}\end{array}$ & \begin{tabular}{|l|}
0.1408 \\
{$[0.0155]$}
\end{tabular} & $\begin{array}{l}1.7805^{* * *} \\
{[0.1755]}\end{array}$ & \begin{tabular}{|l|}
1.6537 \\
{$[0.1690]$}
\end{tabular} & $\begin{array}{l}0.1906^{* * *} \\
{[0.0269]}\end{array}$ & \begin{tabular}{|l|}
0.1821 \\
{$[0.0257]$}
\end{tabular} \\
\hline $\begin{array}{l}\text { NFG / } \\
\text { TG }\end{array}$ & $\begin{array}{l}0.0101^{* * *} \\
{[0.0023]}\end{array}$ & \begin{tabular}{|l}
0.0107 \\
{$[0.0022]$}
\end{tabular} & \begin{tabular}{|l}
$0.0689^{* * *}$ \\
{$[0.0254]$}
\end{tabular} & \begin{tabular}{|l|}
0.0793 \\
{$[0.0244]$}
\end{tabular} & \begin{tabular}{|l}
$0.0782^{* * *}$ \\
{$[0.0039]$}
\end{tabular} & \begin{tabular}{|l|}
0.0760 \\
{$[0.0037]$}
\end{tabular} \\
\hline FDG / & $0.1103^{* * *}$ & 0.1063 & 0.3274 & 0.2906 & $0.4913^{* * *}$ & 0.4957 \\
\hline Ak & [0.0270] & [0.0268] & [0.2997] & [0.2950] & {$[0.0460]$} & [0.0447] \\
\hline TkpKr / & $(0.0240)^{* *}$ & $(0.0220)$ & $(0.1953)^{*}$ & $(0.1675)$ & $(0.0205)$ & $(0.0301)$ \\
\hline TopKr & {$[0.0105]$} & {$[0.0100]$} & [0.1166] & {$[0.1071]$} & [0.0179] & [0.0164] \\
\hline LikVr / & $(0.0306)^{* * *}$ & $(0.0306)$ & $(0.2922)^{* * *}$ & $(0.2787)$ & 0.0025 & 0.0047 \\
\hline Ak & [0.0048] & [0.0048] & [0.0534] & [0.0530] & [0.0082] & [0.0080] \\
\hline Ak Log & $\begin{array}{l}0.0044^{* * *} \\
{[0.0008]}\end{array}$ & \begin{tabular}{|l|}
0.0043 \\
{$[0.0006]$}
\end{tabular} & $\begin{array}{l}0.0354^{* * *} \\
{[0.0086]}\end{array}$ & \begin{tabular}{|l|}
0.0332 \\
{$[0.0057]$}
\end{tabular} & $\begin{array}{l}(0.0022)^{*} \\
{[0.0013]}\end{array}$ & \begin{tabular}{|l|}
0,0001 \\
{$[0.0009]$}
\end{tabular} \\
\hline Tüfe & $\begin{array}{l}0.0404^{* *} \\
{[0.0193]}\end{array}$ & $\begin{array}{l}0.0409 \\
{[0.0195]}\end{array}$ & $\begin{array}{l}0.5855^{* * *} \\
{[0.2137]}\end{array}$ & $\begin{array}{l}0.5709 \\
{[0.2175]}\end{array}$ & \begin{tabular}{|l|}
$0.2002^{* * * *}$ \\
{$[0.0328]$}
\end{tabular} & \begin{tabular}{|l|}
0.2072 \\
{$[0.0328]$}
\end{tabular} \\
\hline
\end{tabular}




\begin{tabular}{|l|l|l|l|l|l|l|}
\hline Gsyih & $0.0064^{*}[0.0037]$ & $\begin{array}{l}0.0066 \\
{[0.0038]}\end{array}$ & $\begin{array}{l}0.0563 \\
{[0.0416]}\end{array}$ & $\begin{array}{l}0.0575 \\
{[0.0425]}\end{array}$ & $\begin{array}{l}0.0182^{* * *} \\
{[0.0064]}\end{array}$ & $\begin{array}{l}0.0194 \\
{[0.0064]}\end{array}$ \\
\hline $\begin{array}{l}\text { Ihr İth } \\
\text { KO }\end{array}$ & $\begin{array}{l}0.0003 \\
{[0.0007]}\end{array}$ & $\begin{array}{l}0.0002 \\
{[0.0007]}\end{array}$ & $\begin{array}{l}0.0046 \\
{[0.0074]}\end{array}$ & $\begin{array}{l}0.0040 \\
{[0.0075]}\end{array}$ & $\begin{array}{l}(0.0011) \\
{[0.0011]}\end{array}$ & $\begin{array}{l}(0.0007) \\
{[0.0011]}\end{array}$ \\
\hline F-Test & $8.01^{* * *}$ & & $6.02^{* * *}$ & & $3.43^{* * *}$ & \\
\hline $\begin{array}{l}\text { Hausma n } \\
\text { Testi }\end{array}$ & & $118.89^{* * *}$ & & $88.96^{* * *}$ & & $17.75^{* * *}$ \\
\hline $\begin{array}{l}\text { Breusch- } \\
\text { Pagan }\end{array}$ & & $196.28^{* * *}$ & & $100.09^{* * *}$ & & $30.15^{* * *}$ \\
\hline $\mathbf{R}^{\mathbf{2}}$ & 0.2964 & 0.3057 & 0.2652 & 0.2749 & 0.5352 & 0.5494 \\
\hline $\begin{array}{l}\text { Wald Ki } \\
\text { Kare }\end{array}$ & & $350.62^{* * *}$ & & $272.43^{* * *}$ & & $904.31^{* * *}$ \\
\hline F değeri & $29.33^{* * *}$ & & $21.72^{* * *}$ & & $73.63^{* * *}$ & \\
\hline Gözlem & 769 & 769 & 769 & 769 & 769 & 769 \\
\hline Banka & 19 & 19 & 19 & 19 & 19 & 19 \\
\hline
\end{tabular}

Not: * \%10anlamlılığı ** \% 5anlamlılı̆ı, *** \% 1anlamlıı̆ğı ifade etmektedir. [ ] içindeki değerler ise standart hatalardır. ( ) içindeki değerler negatif değerlerdir.

Analize dahil değiş̧en bağımsız değişkenlerin bağımlı değişkenleri etkileme yönü aşağıdaki tabloda gösterilmektedir.

\begin{tabular}{|l|c|c|c|}
\hline & $\begin{array}{c}\text { Aktif } \\
\text { Karlıı̆ı̆ }\end{array}$ & $\begin{array}{c}\text { Özkaynak } \\
\text { Karlılığı }\end{array}$ & $\begin{array}{c}\text { Net Faiz } \\
\text { Marjı }\end{array}$ \\
\hline Krediler / Aktifler & 0 & 0 & 0 \\
\hline Özkaynak /Aktifler & + & 0 & + \\
\hline Mevduat/Aktifler & + & + & + \\
\hline Personel Giderleri / Aktifler & + & + & + \\
\hline Net Faiz Geliri / Toplam Gelir & + & 0 & + \\
\hline Faiz Dışı Gelir / Aktifler & + & - & 0 \\
\hline Takipteki Krediler / Toplam Krediler & - & - & - \\
\hline Likit Varlıklar / Aktifler & - & + & + \\
\hline Aktif Büyüklüğü & + & + & + \\
\hline TÜFE & + & 0 & 0 \\
\hline GSYiH & + & 0 & \\
\hline İhracatın İthalatı Karşılama Oranı & 0 & & + \\
\hline
\end{tabular}

(+) pozitif yönlü ilişki, (-) negatif yönlü ilişki, (0) ilişkinin olmadığını göstermektedir.

Personel için yapılan giderin aktif kârlılı̆ını artırdığı bu durumun personelin motive olma derecesi ne kadar yüksek olursa bankaya sağlayacağı hizmetin de o kadar verimli olacağı varsayımından kaynaklandığı düşünülmektedir. Faiz gelirlerinin toplam gelirler içerisindeki payının artmasının aktif kârlıı̆̆ını artırdığı görülmektedir. Bankaların ana faaliyet konuları üzerine eğilmeleri bankanın aktif kârlııı̆ını artırmaktadır. Bankaların ölçek ekonomis- inin artmasının aktif kârlılığını artırdığı görülmekte ve bu durumun ölçeğin artmasının maliyet azaltıcı tasarrufların ortaya çıkmasından kaynaklandığı düşünülmektedir.

Tüketici fiyat endeksindeki artışın aktif kârııı̆ını artırdığı görülmektedir. Enflasyonun faiz oranlarının artmasına neden olduğu bu durumun da bankaların kârlılığına olumlu bir şekilde yansıdığından kaynaklandığı düşünülmektedir. Gayrisafi yurtiçi 
hasıla oranının artmasının aktif kârlılığını artırdığı görülmüştür. Bu durumun da gayrisafi yurtiçi hasıla oranının artmasının kredi arz ve talebini artırdığından kaynaklandığı düşünülmektedir. Bankaların yükümlülüklerini ve borçlarını istenildiğinde ödeme gücünü artırmak için aktif içindeki likit varlık payını artırmasının aktif kârlılığını azalttığı görülmektedir. Bu durumun bankaların gereğinden fazla likit varlık bulundurarak yatırımlarını azalttığından kaynaklandığı düşünülmektedir. Krediler içindeki takibe düşen kredi oranının artmasının aktif kârlılığını azalttığı görülmektedir. Bu durumun bankaların verdiği krediyi tahsil edememesinin gerçekleştireceği yeni yatırımlarını azalttığından kaynaklandığı düşünülmektedir.

Aktif kârlılığında olduğu gibi motive olduğunda bankaya sağladığı verimin de artması sebebiyle personel için yapılan giderlerin, bankaların mevduat sahiplerinden aldığı borcu aktifleriyle karşılayabilme oranının artmasının özkaynak kârıılığını artırdığı görülmektedir. Bankalar genellikle fonları özkaynaklar ve yabancı kaynaklar olmak üzere iki kaynaktan sağlamaktadırlar. Özkaynaklar kendi bünyelerinden sağladıkları kaynaklar, yabancı kaynaklar ise üçüncü kişilerden borçlanma yoluyla sağladıkları kaynaklardır. Bankalar fon kaynaklarının büyük bir kısmını yabancı kaynaklardan sağlamaktadır. Yabancı kaynaklarını ise genellikle mevduatlardan sağlamaktadır. Mevduatların, mevduat sahipleri tarafından sorunsuz bir şekilde tahsil edilebilmesi izleniminin bankaya yatırılan mevduat oranını artırdığı ve bu durumun kâra olumlu bir şekilde yansıdığından özkaynak kârlılığını artırdığı düşünülmektedir. Gelirler içindeki faiz gelirlerinin artmasının özkaynak kârlıı̆̆ını artırdığı görülmektedir. Bankaların ölçek ekonomisinin artmasının özkaynak kârlılığını artırdığı görülmektedir. Bu durumun ölçeğin artmasının maliyet azaltıcı tasarrufların ortaya çıkmasından kaynaklandığı düşünülmektedir. Son olarak ise tüketici fiyat endeksinin de özkaynak kârlılığını artırdığı görülmektedir. Bu durumun enflasyonun artmasının faiz oranlarının artmasına neden olduğu, bunun kârlılığa olumlu yönde yansıdığından kaynaklandığı düşünülmektedir. Bankaların yükümlülüklerini ve borçlarını istenildiğinde ödeme gücünü artırmak için aktif içindeki likit varlık payını artırmasının özkaynak kârlılığını azalttığı görülmektedir. Bu durumun bankaların gereğinden fazla likit varlık bulundurarak yatırımlarını azalttığından kaynaklandığı düşünülmektedir. Krediler içindeki takibe düşen kredi oranının artmasının özkaynak kârlılığını azalttığı görülmektedir. Bu durumun bankaların verdiği krediyi tahsil edememesinin gerçekleştireceği yeni yatırımlarını azalttığından kaynaklandığı düşünülmektedir. Sermaye yeterliliği ölçütünün, bankaların faaliyet çeşitliliğinin ve gayrisafi yurtiçi hasılanın özkaynak kârııı̆ı üzerinde istatistiki olarak anlamlı bir etkisi bulunamamıştır.

Aktif ve özkaynak kârlııı̆ında olduğu gibi bankaların mevduat sahiplerinden aldığı borcu aktifleriyle karşılayabilme oranının artmasının net faiz marjını da artırdığı görülmektedir. Bu durumun mevduat sahiplerinin bankaya duydukları güveni artırmasından ve bunun bankaya daha çok mevduat kazandırdığından kaynaklandığı düşünülmektedir. Personel için yapılan giderlerin net faiz marjını artırdığı görülmektedir. Bu durumun personele yapılan harcamaların personelin motivasyonunu artırdığı ve böylelikle personelin banka için daha verimli çalıştığından kaynaklandığı düşünülmektedir. Sermaye yeterlilik oranın artmasının da net faiz marjını artırdığı görülmektedir. Bu durumun bankaların karşılaşabileceği olası olumsuz durumların üstesinden kolayca gelebileceği izlenimi verdiğini böylelikle bankalara olan güveni artırdığını ve bu durumun kâra olumlu bir şekilde yansıdığından kaynaklandığı düşünülmektedir. Faiz gelirlerinin toplam gelirler içerisindeki payının artması ve bankanın faaliyet çeşitliliğinin artmasının da net faiz marjını artırdığı görülmektedir. Son olarak ise gayrisafi yurtiçi hasıla oranının artmasının net faiz marjını artırdığı sonucuna ulaşılmıştır. Bu durumun ise gayrisafi yurtiçi hasıladaki artışın kredi arz ve talebini artırdığından kaynaklandığı düşünülmektedir. Bankaların ölçek ekonomisinin ise net faiz marjı ile ters orantılı olduğu görülmüştür. Başka bir deyişle bankalar ölçek ekonomisini artırdığında net faiz marjı düşecek, ölçek ekonomisini azalttığında ise net faiz marjı artacaktır. Bankaların yükümlülüklerini ve borçlarını istenildiğinde ödeme gücünün ve krediler içindeki takibe düşen kredi oranının net faiz marjı üzerinde istatistiki olarak anlamlı bir etkisi bulunamamıştır.

Çalışmadan elde edilen diğer bir sonuç ise kredi riskinin ve ihracatın ithalatı karşılama oranının kredi arz ve talebi etkilemesinin her üç kârlılık göstergesi üzerinde de istatistiki olarak anlamlı bir etkisi bulunamamıştır.

Sonuçlara genel olarak bakıldığında gayrisafi yurtiçi hasıla oranının istatistiki olarak \% 10 anlamlılık düzeyiyle aktif kârlıığı üzerinde, bankaların yükümlülüklerini ve borçlarını istenildiğinde ödeme 
gücünün \% 10 anlamlılık düzeyiyle özkaynak kârlıı̆̆ üzerinde, ölçek ekonomisinin ise \% 10 anlamlılık düzeyiyle net faiz marjı üzerinde belirleyici bir değişken olduğu tespit edilmiştir. Bu sonuçlara ek olarak ticari bankaların kârlılıklarında kendi finansal bünyelerinin ve operasyonel başarılarının büyük önem arz ettiği görülmektedir. Bankaların kârlarını maksimize etmek için gereğinden fazla likit varlık bulundurmak yerine bunları yatırıma dönüştürmelerinin, faaliyet çeşitliliklerini ve mevduat oranlarını artırmalarının faydalı olacağı düşünülmektedir.

Yapılan çalışmadan elde edilen sonuçlar literatürde yer alan görüşlerin çoğunu desteklemektedir. Ayrıca literatüre ters bazı sonuçlar da bulunmaktadır. Bu farklılıkların çalışmanın konusunu oluşturan dönemlerin farklı olmasından ve çalışmaların yapıldığı ülkelerin kendine has koşullarından kaynaklandığı düşünülmektedir.

\section{SONUÇ}

Bu çalışmanın amacı Türkiye'de ticari bankacılık sektörünün kârlıı̆̆ını etkileyen faktörlerin neler old- uğunu ortaya koymaktır. Elde edilen analiz sonuçları incelendiğinde Türk ticari bankaların sermaye yeterlilik oranı arttıkça aktif kârlılığının da arttığı görülmektedir. Bankaların yeterli sermayeye sahip olmalarının müşteriler üzerinde bankaların karşılaşabileceği olası olumsuz durumların üstesinden kolayca gelebileceği izlenimi verdiğini böylelikle bankalara olan güveni artırdığını ve bu durumun kâra olumlu bir şekilde yansıdığı düşünülmektedir.

Sonuç itibariyle, Türk bankalarının karlılıklarını artırabilmeleri için öncelikle sermaye yeterliliklerini sağlamış olmaları gerekmektedir. Çalışmanın sonuçları, Türk bankalarında karlılığı artırmanın diğer yollarının ise bankanın ana faaliyet konusuna yönelmesi ancak bu arada etkinliğin sağlanarak takipteki kredi oranının azaltılması ve likitvarlıklara yapılan yatırımların kısılması olduğunu göstermektedir. Ancak, bu çıkarımların, araştırma kapsamındaki döneme ait örneklem ve araştırma modeline dahil edilen değişkenler çerçevesinde geçerli olduğu unutulmamalıdır.

\section{KAYNAKLAR}

Abreu, M. ve Mendes V., (2014) "Commercial Bank Interest Margins And Profitability: Evidence From Eu Countries", Porto Çalışma Tebliği, 122.

Almumanı, M. A., (2013) "Impact Of Managerial Factors On Commercial Bank Profitability: Empirical Evidence From Jordan" International Journal Of Academic Research in Accounting, Finance And Management Sciences, Vol 3 (3), (July), 298-310. S.S.

Alp, A., Ban Ü., Demirgüneş K. ve Kılıç S., (2010) “Türk Bankacılık Sektöründe Karlılığın İçsel Belirleyicileri", istanbul Menkul Kıymetler Borsası Dergisi, 46:1-14.

Alper, D. ve Anbar A., (2011) "Bank Specific And Macroeconomic Determinants Of Commercial Bank Profitability: Empirical Evidence From Turkey", Business And Economics Research Journal, 2(2):139152.

Atasoy, H., (2007) Türk Bankacilık Sektöründe GelirGider Analizi Ve Karlılık Performansının Belirleyicileri, Türkiye Cumhuriyet Merkez Bankası Bankacılık Ve Finansal Kuruluşlar Genel Müdürlüğü, Uzmanlık Yeterlilik Tezi, Ankara.

Auwalin, I. (2011) "An Analysis On The Relationship Of Financing From Banks And Economic Growth in Indonesia", Proceeding Of Fifth Economic Research Symposium - IseI.
Berke, B., (2009) "Avrupa Parasal Birliğinde Kamu Borç Stoku Ve Enflasyon Illişkisi: Panel Veri Analizi", Istanbul Üniv. İktisat Fakültesi Ekonometri ve Istatistik Dergisi, 9:30-55.

Çerçi, G., Kandır S. Y. ve Önal, Y. B., (2012) “Bankalarda Karlılık Analizi: Türk Bankacılık Sektörü Üzerine Bir Uygulama," İstanbul Menkul Kıymetler Borsası Dergisi, 13(50):29-48.

Dağıdır, C., (2010) "Türk Bankacılık Sektöründe Karlılık Ve Makro Ekonomik Değişkenlerle İlişkisi", Ekonomi Bilimleri Dergisi, 2(1):25-33.

Demirel E., Atakişi A. ve Abacıoğlu, S., (2013) "Bankacılık Faaliyet Oranlarının Panel Veri Analizi: Türkiye' Deki Kamu Özel Ve Yabancı Sermayeli Bankaların Durumu", Muhasebe Ve Finansman Dergisi, 7:101-112.

Demirgüç-Kunt A. ve Huizinga H. (1999) "Determinants Of Commercial Bank Interest Margins And Profitabilty: Some International Evidence", The World Bank Economic Review, (2):379-408.

Demirgüç-Kunt, A. ve Maksimovic V., (1998) "Law, Finance, And Firm Growth", Journal of Finance, 53: 2107-2137.

Demirgüç-Kunt A., Laeven L. ve Levine R. (2004) "Regulations, Market Structure, Institutions And The 
Cost Of Financial Intermediation", Journal of Money, Credit and Banking, Xxxvı (3):593-622..

Doğru, C., (2011) "Karlılığın Belirleyicileri Analizi: Teori Ve Orta Ölçekli Bir Banka Uygulaması", Maliye Finans Yazıları, 91: 47-75.

Gülhan, Ü. ve Uzunlar E., (2011) "Bankacılık Sektöründe Karlıı̆ı Etkileyen Faktörler: Türk Bankacılık Sektörüne Yönelik Bir Uygulama", Atatürk Üniversitesi Sosyal Bilimler Enstitüsü Dergisi, 15(1):341368.

İskenderoğlu, Ö., Karadeniz E. ve Atioğlu, E., (2012) "Türk Bankacılık Sektöründe Büyüme Büyüklük Ve Sermaye Yapısı Kararlarının Karlılığa Etkisinin Analizi", Eskişehir Osmangazi Üniversitesi Iktisadi Idari Bilimler Fakültesi Dergisi, 7 (1):291-311.

Jamal, A. A. A., Masyhuri H. ve Mohd R. A. K.,(2012) "Determinants of Commercial Banks Return on Asset: Panel Evidence From Malaysia" Iracast- Internaional Journal Of Commerce Business And Management (ljcbm), 1(3):55-62.

Kaya Türker Y., (2002) "Türk Bankacılık Sektöründe Karlıı̆ın Belirleyicileri: 1997-2000", BDDK Mali Sektör Politikası Dairesi Çalışma Raporları (1):1-16.

Kırkulak- Uludağ, B. ve Gökmen H.,(2011) "Türk Bankacılık Sektörünün Karlılığının Dinamik Yaklaşımla Test Edilmesi", iktisat İsletme Ve Finans, 26(308):71-98.

Kiganda, E. O., (2014) "Effect Of Macroeconomic Factors on Commercial Banks Profitability in Kenya: Case Of Equity Bank Limited", Journal of Economics and Sustainable Development, 5(2):46-56.

King, R. G. ve Levine R., (1993) "Finance and Growth: Schumpeter Might Be Right",

Quarterly Journal of Economics, 108:717-738.

Kolb, R.W. ve Rodriguez, R.J. (1996) "Financial Institutions", Cambridge-Massachusetts: Blackwell Publishers

Levine, R., Loayza N. ve Beck T., (2000) "Financial Intermediation and Growth: Causality and Causes, Journal OfMonetary Economics, 46:31-77.

Levine, R.,(2005). "Finance And Growth: Theory And Evidence". In Philippe Aghion And Steven
Durlauf, Eds. Handbook Of Economic Growth, The Netherlands: Elsevier Science.

Lin, J. Y., Sun, X. ve Wu, H. X., (2012) "Banking Structure, Labor Intensity, And Industrial Growth: Evidence From China", Ssrn Working Paper Series

Maudos, J. ve Guevara, J. F., (2004) "Factors Explaining The Interest Margin The Banking Sectors Of European Union", Journal of Banking and Finance, XxvIII, 2259-2281.

Molyneux, P. ve Thornton J. (1992) "Determinants of European Bank Profitability", Journal Of Banking And Finance, 1173-1178.

Onuonga, S.M., (2014) "The Analysis of Profitability of Kenya's Top Six Commercial Banks: Internal Factor Analysis", American International Journal of Social Sciences, 3(5): 94-103.

Pan, Q. ve Pan M., (2014) "The Impact of Macro Factors On The Profitability of China's Commercial Banks in the Decade After WTO Accession", Open Journal of Social Sciences, 2: 64-69.

Rajan, R. G. ve Zingales L., (1998) "Financial Dependence and Growth", American Economic Review, 88: 559-586.

Riaz, S., (2013) "Profitability Determinants of Commercial Banks in Pakistan", Proceedings Of $6^{\text {th }}$ International Business And Social Sciences Research Conference 3-4 January, , Dubai.

Saunders, A. ve Schumacher L.(2000) "The Determinants of Bank Interest Margins: An International Study", Journal Of International Money And Finance, XIX (6): 813-832.

Taşkın, F. D., (2011) "Türkiye'de Ticari Bankaların Performansını Etkileyen Faktörler", Ege Akademik Bakış, 11(2):289-298.

Tunay, K.B. (2005), “Finansal Sistem: Yapısı, İsleyisi, Yönetimi ve Ekonomisi", İstanbul: Birsen Yayınevi.

Tunay, K. B. ve Silpar A, M., (2006) "Türk Ticari Bankacılık Sektöründe Karlılığa Dayalı Performans Analizi- I", Türkiye Bankalar Birliği Araştırma Tebliğleri Serisi

Türkiye Bankalar Birliği, (2009) "Bankalarımız", www. tbb.org.tr. 